\title{
JAKARTA 2039: MEMBANGUN MONUMEN INGATAN TRAGEDI KEKERASAN
}

\author{
Gilang Saputro* \\ Universitas Indonesia
}

\begin{abstract}
Abstrak
Tulisan ini merupakan kajian terhadap tiga karya komik Jakarta 2039 (2001) karya Zacky bersama Seno Gumira Ajidarama (SGA) dan sandiwara dua bagian Jakarta 2039: 40 Tahun 9 Bulan setelah 13-14 Mei 1998 (2001) yang dibuat berdasarkan cerpen "Jakarta, 14 Februari 2039" (1999) karya Seno Gumira Ajidarma dengan mengacu konsep cultural memory studies. Argumentasi utama dari tulisan ini didasarkan pengangkatan peristiwa kekerasan yang menimpa perempuan Cina pada Mei 1998 di Jakarta dalam komik Jakarta 2039 dan sandiwara dua bagian Jakarta 2039: 40 Tahun 9 Bulan setelah 13-14 Mei 1998 sebagai proses pengulangan ingatan berdasarkan peristiwa yang sama dalam cerpen "Jakarta, 14 Februari 2039". Dalam proses pengalihwahanaan, tema kekerasan Mei 1998 yang sebelumnya ditulis dalam cerpen tetap diposisikan sebagai ingatan yang dimunculkan dalam komik dan naskah drama. Selain itu, isu perempuan dalam indentitasnya sebagai Cina korban perkosaan dan subjek yang trauma dimunculkan secara sadar dalam tiga karya sebagai pengingatan terhadap wacana sejarah kekerasan masa lalu sekaligus pemosisiannya sebagai upaya untuk membangun monumen ingatan pada masa kini dan mencoba untuk menjadikannya sebagai memori kultural masyarakat. Dalam keadaan tersebut, kota Jakarta sebagai ruang dalam kaitannya dengan tragedi kekerasan dikonstruksi.
\end{abstract}

Kata kunci: Jakarta 2039, memori kultural, monumen, kekerasan, kota

\begin{abstract}
This paper is a review of three works; comic Jakarta 2039 (2001) by Zacky and Seno Gumira Zacky Ajidarama (SGA), two-part plays of Jakarta 2039: 40 Tabun 9 Bulan setelah 13-14 Mei 1998 (2001) which is based on Short Story Jakarta, 14 Februari 2039 (1999) by Seno Gumira Ajidarma with reference to the concept of Cultural Memory Studies. The main argument of this paper is based on the reveal of the violence that afflicts the ethnic Chinese women in Jakarta in May 1998. Three works as the repetition of the same memories based on events in short story 'Jakarta, 14 Februari 2039", in the tendency to create and compile an overview of past events in three different works. In addition, the issue of women in their identity as Chinese victims of rape and trauma subjects consciously raised in the three works as a reminder of the discourse of the past history of violence as well positioning of an effort to build a monument to the memory of the present, and make it as a community cultural memory. In such circumstances, the Jakarta city as a space in relation to the violent tragedy constructed.
\end{abstract}

Keywords: Jakarta 2039, cultural memory, monument, violence, city

\footnotetext{
* Makalah ini pernah disampaikan dalam International Graduate Student Conference di Universitas Gadjah Mada pada 2011. Untuk kepentingan penerbitan ini, makalah telah diperbaiki dan mengalami penyempurnaan.
} 


\section{Pendahuluan}

Upaya untuk memahami tindak kekerasan terhadap perempuan etnik Cina pada awal kejatuhan Orde Baru (Orba) 1998 di Indonesia dalam kenyataan faktualnya muncul dalam pelbagai kontraversi. Hal itu tidak dapat terpisahkan terhadap peristiwa Mei 1998 saat Orba jatuh dan lengsernya Soeharto yang ditandai oleh demonstrasi besar-besaran oleh elemen masyarakat dan mahasiswa. Peristiwa di Jakarta, kemudian menjalar dan memicu demonstrasi ke kota besar lainnya di Indonesia. Hingga kini peristiwa tersebut terus dikenang sebagai peristiwa yang dianggap penting dalam sejarah kebangsaan. Pada saat yang sama peristiwa itu terus mengemuka sebagai ingatan yang problematis saat isu perendahan martabat kemanusian dan sentimen terhadap etnik Cina muncul sebagai bagian dari peristiwa kerusuhan. Kebenaran atas fakta sejarah itu hingga kini belum juga terang, padahal peristiwa Mei 1998 adalah ingatan yang penting dalam memahami Jakarta dalam bangunan kebangsaan, termasuk berbagai soal yang menyertainya. Hal itulah yang menjadi dasar telaah atas tiga karya Jakarta 2039.

Isu perempuan etnik Cina sebagai korban kekerasan pada Mei 1998 di Jakarta diangkat sebagai tema dalam karya fiksi oleh Seno Gumira Ajidarma pertama kali dalam cerpen "Clara" (26 Juni 1998) yang menarasikan tokoh perempuan Cina bernama Clara yang diperkosa dan diinterogasi penuh prasangka oleh seorang polisi. Cerpen tersebut pertama dipublikasikan dalam pembacaan cerpen oleh Ratna Riantiarno dan Adi Kurdi di Taman Ismail Marzuki, Cikini, Jakarta (10 Juli 1998), dan dimuat di Republika (16 Juli 1998). Kegiatan pembacaan dan pemuatan dalam media massa tersebut dapat merupakan upaya mengangkat peristiwa kekerasan perempuan Cina dalam karya sastra. Dalam tahap itu, sastra saling sengkarut dengan laporan jurnalistik dan isu merebak di samping pemberitaan yang terus menggambarkan keadaan Jakarta yang saling tumpuk: Soeharto, demonstrasi, dan kerusuhan.

Permasalahan kekerasan terhadap perempuan etnik Cina kemudian dimunculkan kembali dalam "Jakarta, 14 Februari 2039" (1999), cerita pendek yang mengisahkan kelahiran perempuan etnik Cina yang mempertanyakan asal usul kelahirannya yang lahir dari ibu korban perkosaan pada saat kerusuhan Jakarta Mei 1998. Berdasarkan cerpen tersebut, diciptakan komik Jakarta 2039: 40 Tahun 9 Bulan setelah 13-14 Mei 1998 (2001). Proses produksi ulang tidak juga berhenti hingga diterbitkannya naskah drama dengan judul yang sama (2001) yang ditulis berdasarkan cerpen "Clara dan Jakarta 2039". Jakarta diletakkan pada awal judul karya seolah mengingatkan bahwa Jakarta tidak dapat terpisahkan dengan ingatan mengenai peristiwa pemerkosaan terhadap perempuan etnik Cina pada Mei 1998.

Proses penciptaan tiga karya dalam wahana yang berbeda: cerpen "Jakarta, 14 Februari 2039" (1999), komik Jakarta 2039 (2001), dan naskah drama Jakarta 2039: 40 Tahun 9 Bulan setelah 13-14 Mei 1998 (2001), dalam rentang waktu yang berselang secara kronologis tersebut mengindikasikan adanya upaya pemosisian ide perempuan etnik Cina dan kejadian 1998 sebagai ingatan yang terus dipertahankan dan diulang oleh Ajidarma dalam karyanya sebagai medium of cultural memories. Dalam hal itu ingatan terus diulang dan direproduksi. Selain itu, Ajidarma seolah berupaya menjadikan ingatan dalam karya sastra untuk membangun monumen imajiner. Melalui monumen imajiner itulah ada upaya yang bertujuan pada pengetahuan yang dimonumentalisasi dan dapat dirayakan. Dengan cara itu pula, kebenaran dan tafsir atas fakta sejarah terus dipertarungkan.

Berdasarkan pemaparan tersebut, upaya untuk mengetahui hubungan antara pengalihwahanaan satu wahana ke dalam wahana lainnya yang terkait dengan bahasan karya sastra dan ingatan pada tiga karya Jakarta 2039 dapat dirumuskan dalam beberapa pertanyaan: (1) bagaimana isu kekerasan dan pemerkosaan terhadap perempuan Cina pada 1998 diungkapkan dan dipertahankan dalam tiap wahana sebagai ingatan; (2) bagaimana signifikasi pengalihwahanaan tersebut memberikan masa hidup yang lebih lama terhadap karya dan posisinya sebagai ingatan yang terus dipertahankan dan upaya membangun monumen ingatan. Hal itulah yang dibahas dalam tulisan ini dalam perspektif studi memori kultural (cultural memorial studies).

\section{Seno Gumira Ajidarma: Karya Sastra, Memori Kultural, Ingatan, dan Tiga Karya Jakarta 2039}

Seno Gumira Ajidarma lahir di Boston pada 19 Juni 1958. Aktivitas kesusastraannya merentang mulai dari penulis cerpen, puisi, novel, dan esai. 
Selain itu, aktivitasnya sebagai jurnalis juga cendekiawan memosisikan dirinya dalam kondisi yang lengkap. Keterkaitan tersebut dapat dilihat dalam pemosisian Ajidarma dalam kesastraan Indonesia. Posisi tersebut kemudian terkait dengan tiga karyanya sebagai objek dalam tulisan ini: cerpen "Jakarta, 14 Februari 2039" (1999), komik Jakarta 2039; 40 Tahun 9 Bulan setelah 1314 Mei 1998 (2001), dan sandiwara dua bagian Jakarta 2039: 40 Tahun 9 Bulan setelah 13-14 Mei 1998 (2001).

Keterkaitan ketiga karya tersebut dapat dilihat pada isu utama identitas etnik Cina, secara khusus mengenai kekerasan yang dialami perempuan Cina sebagai korban pemerkosaan pada masa sebelum kejatuhan Orba. Beberapa pemikiran dan telaah kritis serta bermacam tulisan mengenai peristiwa itu hingga kini tidak menemukan penyelesaian yang berarti. Isu tersebut kemudian seolah hanya ada dalam sejarah ingatan dalam masyarakat dan pelupaan dalam keberjalanan sejarah Indonesia kini menjadi semacam keniscayaan. Mengenai kejadian itu, Ajidarma menulis catatan yang seharusnya diterbitkan dalam kolom khusus "Surat dari Palmerah" dalam Jakarta-Jakarta, tetapi tidak dapat diterbitkan pada 1998, kemudian diterbitkan dalam Surat dari Palmerah (2002) dalam bagian "Surat-Surat Tidak Terkirimkan".

Bung, penculikan para aktivis dan pemerkosaan sistematis terhadap perempuan-perempuan etnis Tionghoa mengungkapkan sebuah dunia yang yang mengerikan. Ternyata kita bertetangga dengan makhluk-makhluk yang menganggap kekerasan dan kekejaman adalah pekerjaan mulia. Semakin mengerikan kalau perbuatan yang tidak manusiawi itu dengan santai disebut kesalahan prosedur. Apakah yang bisa lebih mengerikan dari ini?...Saya tidak habis pikir menemui banyak kenyataan banyak orang tiada bergeming mendengar berita-berita tentang penculikan dan pemerkosaan itu. Banyak orang ternyata tenang-tenang saja. Cuek-cuek saja.... begitu mendengar soal pemerkosaan, kalau tidak mengatakan "Apakah pernyataan itu valid?" Atau "Apakah sudah di cross chek?" Maka paling-paling akan bilang, "Oh, kasihan."...Kita ini seperti bangsa berhati batu... Apa yang bisa kita perbuat? Produk pendidikan, produk kebudayaan, dan produk moralitas nyatanya adalah terbentuknya bangsa yang terbiasa dengan ketakutan. Seorang presiden yang uzur telah tumbang, tapi itu terbukti belum mengubah apa-apa-segalanya malahan bertambah buruk. Ketakutan berkuasa. Kebodohan merajalela. Mulut- mulut ngablak tanpa isi....Bung, apa kata Anda? Bicaralah kepada diri Anda sendiri. Salam dari Palmerah...NB, Sukab bertanya, terbuat dari apakah kejahatan?

Fragmen di atas dapat dilihat sebagai sikap Ajidarma yang secara sadar melihat peristiwa dan kejadian tragedi Mei 1998 sebagai situasi yang bertentangan dengan kemanusiaan dan kebiadaban sejarah dan negara dalam memosisikan peristiwa pemerkosaan dan kekerasan terhadap etnik Cina. Ajidarma dengan demikian sebagai pengarang juga dapat ditempatkan sebagai subjek berkesadaran. Dalam keadaan itulah karya sastra selanjutnya yang mengangkat tema serupa dapat dipahami sebagai penggugatan terhadap versi kebenaran peristiwa, juga sebagai pengungkapan ingatan kekerasan. la juga merasa berkewajiban untuk mengangkat masalah kekerasan itu dalam teks kebudayaan dan melihatnya sebagai pengetahuan yang harus diungkap dan diteruskan bukan hanya sebagai ingatan, melainkan sebagai cara untuk melihat posisi kemanusiaan dalam praktik sosial dan kebangsaan. Tidak berlebihan jika kesadaran itu diwujudkan Ajidarma dalam karya sastra yang dalam hal itu ia memecah kebuntuan jurnalisme yang dibungkam dan mengaburkan fakta dalam kefiksiannya. Melalui karyanya Ajidarma memanfaatkan hal itu.

Ann Rigney (2008) menempatkan karya sastra dalam relasi dengan nilai kultural dalam beberapa poin: (1) relay station, narasi yang berifat fiksional berdasarkan pengingatan ulang yang dapat mengambarkan situasi yang digambarkan berdasarkan ingatan; (2) stabilizers, karya sastra dapat dengan sukses menghadirkan secara partikular suatu periode dalam cara mengingatkan dalam suatu keadaan kultural tertentu dalam hubungannya sebagai pengungkapan kembali; (3) catalyst, berhubungan dengan kekuatan imajinatif pengarang dan fiksi digunakan sebagai cara untuk menggambarkan "kebaruan" suatu topik sebagai suatu ingatan kultural; (4) object of recollection, karya sastra bukan hanya bekerja sebagai media untuk mengingat, melainkan dirinya menjadi objek rekoleksi dalam media lain dalam mekanisme ekspresi; (5) calibrator, berhubungan dengan sastra kanon sebagai monumen yang merefleksikan secara kritis praktik ingatan yang dominan, termasuk revisinya terhadap teks kanon.

Karya sastra sebagai teks penyimpanan ingatan kultural dalam keberadaannya menyimpan sejarah masa lalu peristiwa yang dianggap penting untuk terus disimpan. Dalam keadaan itu, pembacaan atau interpretasi terhadapnya 
merupakan cara untuk memosisikan ingatan terhadap suatu peritiwa masa lalu terus ada dan dapat dilihat sebagai sesuatu yang hadir dalam kekiniannya. Hal tersebut berkaitan dengan karya sastra sebagai cara untuk membangun monumen. Monumen dipahami sebagai bangunan yang nyata yang diciptakan sebagai rujukan terhadap kebenaran kondisi atau situasi historis. Dalam pemahaman itu subjek secara individual menggunakan perangkat budaya sebagai alat untuk membantu dalam mewakili masa lalu serta sebagai simbol yang ditulis dalam buku, museum, dan monumen untuk membantu mengingat beberapa kejadian atau fakta. Selanjutnya, ingat subjek secara sosial yang dibangun dalam ketergantungan terhadap orang lain yang memberikan infromasi untuk memperbarui ingatan mengenai peristiwa itu dapat meningkatkan ingatan atau justru menyertakan kesalahan. Hal itu bergantung pada informasi yang diberikan (L. Henry, 2008).

Dalam pengertian tersebut, sastra sebagai teksyangmemuatsejarah peristiwa memungkinkan sebagai upaya untuk membangun monumen dalam artian yang tidak bersifat berwujud secara fisik sebagai bangunan. Hal itu memungkinkan untuk memberikan pengetahuan subjek untuk membentuk memori kultural masyarakat yang terdiri atas subjek dengan pengetahuannya. Aleida Asman dalam rumusannya melihat memori kultural dalam dua fungsi yang terpisah. Pertama, sebagai pilihan yang terbatas pada teks suci, karya seni, atau peristiwa penting sejarah dalam kerangka kerja yang bertahan. Kedua, sebagai penyimpanan dokumen dan artefak dari sejarah masa lalu yang sama sekali tidak memenuhi standar, tetapi membuatnya dianggap penting atau menarik dan tidak membiarkannya dilupakan secara total. Apresiasi terhadapnya mengulangi dan melanjutkan perhatian individu dan publik. Hal itu merupakan ciri khas objek dalam kajian memori kultural sebagai cara untuk melestarikan dan menarik perhatian umum terhadap suatu memori yang diacu. Rujukan empati dan perhatian khusus pada sejarah sebagai dua sisi yang ada dalam dinamika memainkan memori kultural (Assmann, 2008).

Seturut dengan pemahaman tersebut, Lachman secara khusus melihat sastra sebagai ingatan budaya, bukan hanya sebagai alat perekam sederhana, melainkan juga sebagai tindakan mengingatkan, yang di dalamnya pengetahuan disimpan oleh suatu kebudayaan dan hampir semua teks kebudayaan diproduksi dalam masalah

\section{" Menulis adalah tindakan dalam} ruang memori. Keterlibatan dengan teks pada suatu kebudayaan. Setiap teks baru itu mencerminkan (baik sebagai konvergensi atau divergensi maupun asimilasi atau tolakan) dan berdiri dalam sebuah hubungan timbal balik dengan konsepsi ingatan yang menyiratkan budaya itu."

\section{(Lachman, 2008)}

kebudayaan tersebut dibentuk. Menulis adalah tindakan dalam ruang memoridengan melibatkan teks dalam suatu kebudayaan. Setiap teks baru itu mencerminkan (baik sebagai konvergensi atau divergensi maupun asimilasi atau tolakan) dan berdiri dalam sebuah hubungan timbal balik dengan konsepsi ingatan yang menyiratkan budaya itu (Lachman, 2008).

Peristiwa kekerasan terhadap perempuan Cina dalam sejarah keruntuhan Orde Baru dalam keterkaitannya dengan pandangan di atas dalam karya cerita pendek "Jakarta 2039" diangkat sebagai peristiwa yang dianggap penting dalam teks sastra. Sejarah peristiwa tersebut dimungkinkan direkam dan ditafsirkan oleh pengarang dan dalam perjalanan sejarah peristiwa kekerasan tersebut menjadi pengetahuan. Apresiasi terhadapnya merupakan cara untuk melanjutkan ingatan, yang pada saat yang sama melihat kebenaran mengenai suatu peristiwa dan saat yang sama pula pertarungan antar berbagai wacana dalam menafsirkan kebenaran mengenai fakta sejarah kekerasan terhadap perempuan etnik Cina menjadi suatu hal yang tidak dapat dihindari.

Dalam pemroduksian teks selanjutnya, komik Jakarta 2039 menjadi cara untuk mengulang kembali ingatan mengenai kekerasan terhadap perempuan Cina dalam medium yang baru. Dalam komik dimungkinkan untuk ditampilkan gambaran reflektif yang lebih hadir secara nyata dalam gambar berturutan, yaitu citra visual dan peristiwa ditampilkan dalam gambar yang mewakili peristiwa yang ditampilkan dalam cerpen. Sebagai naskah, peristiwa ditampilkan melalui penghadiran tokoh dan penggambaran suasana dan ruang yang lebih nyata dalam adegan dan penciptaan pemeran yang melibatkan karakter dan dialog dalam perannya serta petunjuk pemanggungan yang 
memungkinkan situasi ruang dan waktu serta suasana dapat ditunjukkan dalam kondisi yang lebih lengkap. Hal itu berbeda dengan drama dalam bentuk pertunjukkan karena peristiwa dimungkinkan hadir sebagai penghadiran naskah dan pewujudan elemen yang sebelumnya hanya dituliskan dan detail peristiwa ditampilkan. Hal itu memungkinkan terjadinya rekonstruksi peristiwa dalam kekiniannya.

\section{Tiga Karya: Penghadiran dan Pengulangan Peristiwa Masa Lalu}

Selain ingatan terhadap kekerasan yang dialami oleh perempuan etnik Cina seperti pada bagian subbahasan sebelumnya, penting untuk dilihat bagaimana Ajidarma hanya mentransfer ingatan yang sama ke dalam tiga wahana yang berbeda: cerpen, komik, dan naskah drama. Dalam cara demikian, Ajidarma pun mengulang ingatan yang pernah dia tuliskan sebagai bentuk gugatan terhadap peristiwa yang melekat sebagai memori kultural dalam masyarakat Indonesia dalam kesejarahan kejatuhan Orde Baru, sebagai cara mengingat masa lalu sekaligus membangun ingatan yang baru, dan sebagai collective imagination of the past. Dalam hal itu dapat dipahami bahwa karya sastra memungkinkan untuk mengangkat suatu permasalahan yang diingat sebagai masa lalu dalam keadaan sekarang: Jakarta 2039: 40 Tahun 9 Bulan setelah 13-14 Mei 1998.

Judul ketiga karya tersebut menunjukkan bahwa Ajidarma membatasi ruang historis yang lampau dalam perkiraannya ke depan. Dirinya menulis tentang ingatan masa lalu dalam kekinian dan ramalannya terhadap masa depan. Selain itu, Jakarta pun jelas bukan hanya diposisikan sebagai ruang tempat peristiwa berlangsung, melainkan juga sebagai cara untu mengingat bahwa ingatan tentang kekerasan selalu bersanding dengan konstruksi atas ruang, suatu keadaan traumatik yang menimpa perempuan etnik Cina korban pemerkosaan di Jakarta yang ditampilkan dalam tiga karya.

\section{Cerpen}

“Jakarta, 14 Februari 2039" Pukul 22:15. TERNYATA AKU ANAK HASIL PEMERKOSAAN

Hujan deras di luar dinding apartemen. Dinding kaca apartemen yang tebal tidak memperdengarkan bunyi hujan itu, tapi air hujan menggelontor kencang di dinding kaca. Rupa-rupanya tiupan angin yang keras berhembus dan menghempas. Terlihat helikopter patroli polisi menyorotkan lampu biru di antara gedung-gedung bertingkat. Dua penjahat berlari sia-sia dari lorong ke lorong dalam kejaran helikopter. Orang-orang yang tidak merasa bersalah tenang-tenang saja di sepanjang kaki lima yang riuh. Kedua penjahat itu akhirnya terpojok di gang buntu. Polisi menodong dari helikopter dengan bantuan cahaya laser. Bintik merah terus menerus menempel di dahi kedua orang itu. "Menyerahlah kalau tidak ingin kepalamu pecah," terdengar polisi berteriak lewat pengeras suara. Seorang wanita menengok sebentar adegan itu dari balik jendela. Lantas masuk kembali. Ia memasang sebuah compact disc ke dalam kamera, duduk di sofa, lantas mengarahkan sebuah remote control kepada kamera yang terpasang di hadapannya. la mulai bicara.

\section{(“Dunia Sukab", 2001:131-132)}

Narasi diawali oleh latar waktu dan peristiwa tokoh Aku yang mengetahui identitasnya, yaitu sebagai anak hasil pemerkosaan dalam sudut pandang orang ketiga yang serba tahu. Kemudian, narasi dalam kilas balik kejadian bagaimana tokoh Aku mendapatkan keterangan tentang identitasnya dalam kota sebagai ruang yang dideskripsikan dalam suasana yang muram dan kemunculan tokoh lain sebagai penguat cerita. Peralihan sudut pandang pencerita terjadi dalam dua sudut pandang, yaitu sebagai orang ketiga atau tokoh Aku sebagai orang pertama. Hal itu digabungkan menjadi satu peristiwa awalan yang membuka narasi, yang di dalamnya peristiwa tersusun sebagai jejak rekam yang kronologis yang mempertimbangkan waktu dan kejadian.Peralihan sudut pandang pencerita terjadi dalam dua sudut pandang, yaitu sebagai orang ketiga atau tokoh Aku sebagai orang pertama. Begitulah selanjutnya dalam cerpen narasi tentang tokoh Aku sebagai anak korban perkosaan itu dikonstruksi.

Terdapat beberapa citraan yang dapat dilihat dalam fragmen di atas: (1) penglihatan, (2) pendengaran, dan (3) gerak. Citraan tersebut dikembangkan berdasarkan kronologi peristiwa yang melibatkan waktu dan ruang serta kemunculan tokoh Aku dalam sudut pandang penceritaan yang serba tahu. Fragmen di atas sebagai permulaan cerita menjadi penting dan bagaimana sejak awal ingatan atau kejadian pemerkosaan terhadap perempuan Cina sebagai tragedi sejarah ditampilkan dalam keadaan tersirat (kalimat 1-3) dalam peristiwa yang tidak dianggap terjadi atau dengan kata lain tidak dihiraukan kebenarannya dalam analoginya 
dengan peristiwa "hujan deras", "dinding tebal" yang membuat "bunyi hujan tidak terdengar", serta "tiupan angin kencang" sebagai metafora dari pelupaan dan ketidakpedulian "tenangtenang saja". Selanjutnya, peristiwa dihadirkan dalam citraan visual dan gerak tokoh seorang wanita. Peristiwa dalam fragmen tersebut dengan kata lain menghadirkan citraan dengan lengkap.

\section{Komik}

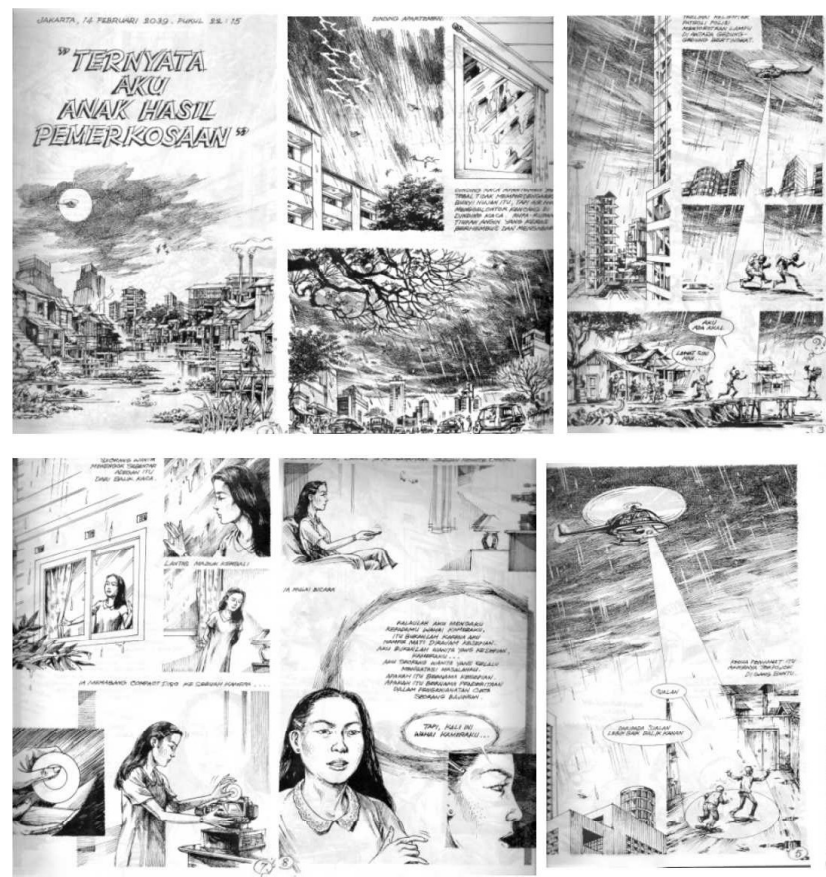

Panel yang dinukil dari komik di atas jelas didasarkan deskripsi cerpen yang sama, tetapi narasi dibangun berdasarkan gambar berturutan. Setiap keterpautan panel dan peralihannya dapat digolongkan ke dalam tiga jenis peralihan panel sekaligus: (1) waktu kewaktu, peralihan itu dapat terlihat di panel 1-5, yang memperlihatkan closure yang sedikit, yaitu situasi Kota Jakarta yang terbagi dalam keadaan yang muram dengan penggambaran situasi ruang yang kumuh, (bantaran) kali, cerobong asap, sungai yang kotor sekaligus kota dalam gedung tinggi, dan aktivitasnya. Dalam peralihan itu pembaca sekaligus diarahkan untuk melihat satu benda (helikopter) yang mendapatkan closure di tengah panel di panel pertama; (2) subjek kesubjek dalam proses aksi ke aksi. Dalam tahap itu panel menunjukkan peralihannya berdasarkan aksi subjek, yaitu dua orang penjahat dalam pelariannya dari penangkapan polisi yang ada di dalam helikopter serta subjek tokoh perempuan Aku yang muncul dalam panel lain yang melihat kejadian penangkapan dalam penggambaran wajah yang muram dalam melakukan aktivitasnya berdiri di jendela, menatap ke luar jendela, melangkah, mengambil $C D$, kemudian
Namun, hal itu muncul dalam bentuknya yang virtual dalam persepsi pembaca sebagai citraan yang imajinatif yang memanfaatkan bahasa.

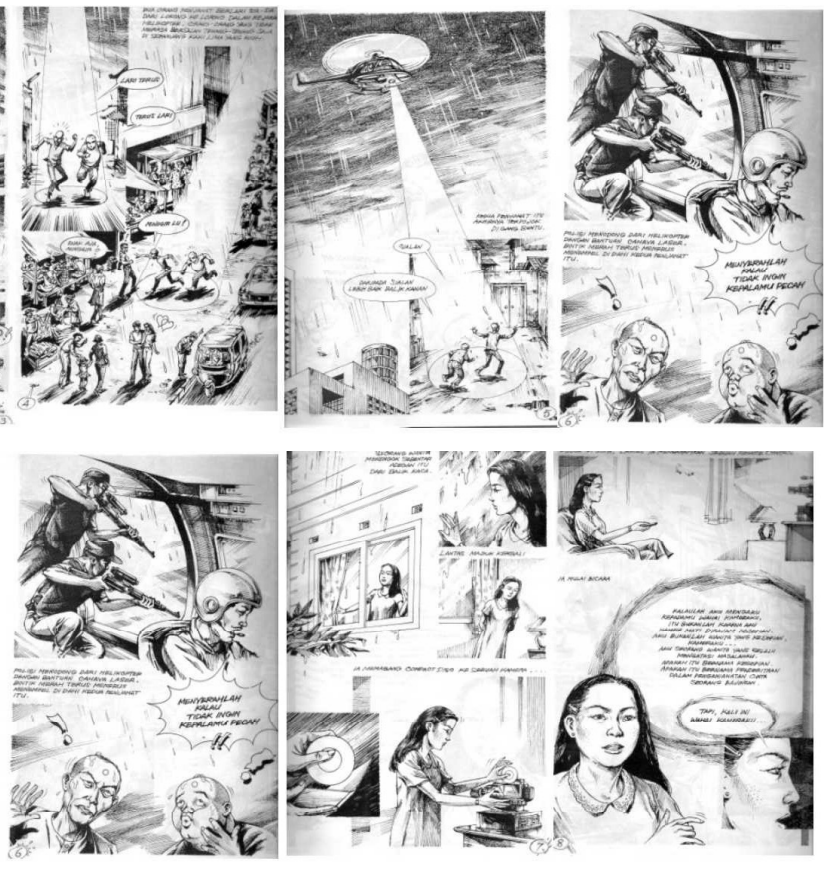

(Jakarta 2039, 2001: Panel 1-21).

memasukannya ke dalam alat perekam; (3) peralihan adegan ke adegan: panel disusun secara dua garis besar adegan, yaitu penangkapan dua penjahat dan kehidupan tokoh Aku.

Dalam beberapa nukilan panel di atas, terdapat beberapa hal yang dapat dilihat dalam penghadiran peristiwa dan tokoh, yaitu (1) peristiwa dalam narasi cerpen ditampilkan dalam penggambarannya dilengkapi dengan teks sesuai dengan apa yang ada dan dituliskan dalam cerpen dan kota sebagai ruang terjadinya peristiwa, yaitu Kota Jakarta yang suram dan bangunan, serta (2) perempuan etnik Cina ditampilkan dalam potret yang stereotypical, berambut lurus, berwajah sedikit bulat (hampir oval), dan mata sipit. Jelas bahwa tokoh perempuan yang selanjutnya di tulis sebagai Aku adalah perempuan etnik Cina. Citraan bangunan yang sebelumnya metaforis dan peristiwa hujan ditampilkan dalam kesan yang hanya merupakan peristiwa. Keadaan itu tidak memberikan ruang untuk metafora ingatan dan sejarah peristiwa kekerasan yang dilupakan seperti dalam cerpen. 
Selain itu, dua tokoh penjahat ditampilkan dalam wujudnya yang komikal, lusuh, satu di antaranya berwajah tambun dengan kepala yang gundul dan satu dalam tampilan fisik yang kurus dalam pelarian dan berakhir dalam todongan senjata dengan titik merah di kening keduanya. Peristiwa penangkapan divisualisasikan secara dramatis dengan dua polisi yang menodongkan senjatanya. Penghadiran narasi cerpen dalam bentuk lain dapat dilihat sebagai kemungkinan untuk menghadirkan teks dan gambar sekaligus dalam suatu penggambaran yang berturut melalui keterhubungan satu panel dengan panel lainnya dalam kronologi peristiwa, termasuk menghadirkan peristiwa dalam closure yang memungkinkan deskripsi peristiwa dalam situasi yang terjadi pada tokoh hadir pada waktu yang bersamaan dalam jukstaposisi satu peristiwa dengan peristiwa lain yang bertumpuk dalam satu panel. Dengan kata lain, melalui gambaran yang spasial peristiwa dihadirkan dan hal tersebut berpengaruh dalam rekonstruksi ingatan yang sebelumnya tidak tergambarkan (virtual).

Drama$$
\text { II }
$$

Jakarta, Februari 2039

PANGGUNG GELAP, TERDENGAR SUARA HUJAN DAN HELIKOPTER. TERDENGAR JUGA SUARA MASSA. LAMPU FADE IN MENYOROT TUKANG CERITA YANG BERBICARA KEPADA PENONTON

\section{Tukang Cerita:}

Para penonton yang terhormat, empatpuluh tahun sembilan bulan telah berlalu semenjak tanggal 13 dan 14 Mei 1998. Jakarta masih sama panas dan sama busuknya seperti dulu. Untung masih ada musim hujan, meski jadwalnya semakin tidak jelas. Jadi inilah hujan pada jam sepuluh malam lebih lima belas menit, tanggal 14 bulan februari tahun 2039 di Jakarta.

Di antara gedung-gedung pencakar langit, terlihat sebuah helikopter melintas, mengejar dua penjahat yang berlari sia-sia dari lorong ke lorong. Helikopter patroli polisi itu menyorotkan lampu biru di antara gedung-gedung bertingkat. Orangorang yang merasa tidak bersalah tenangtenang saja di sepanjang kaki lima yang riuh. Kedua penjahat itu akhirnya terpojok di gang buntu. Polisi menodong dari helikopter dengan bantuan cahaya laser. Bintik merah terus-menerus menempel di dahi kedua orang itu. "menyerahlah, kalau tidak ingin kepalamu pecah," terdengar polisi itu berteriak lewat pengeras suara. "...melalui gambaran yang spasial peristiwa dihadirkan dan hal tersebut berpengaruh dalam rekonstruksi ingatan yang sebelumnya tidak tergambarkan (virtual). "

Di sebuah apartemen

LAMPU MENYOROT ANAK CLARA, YANG MENENGOK KE LUAR JENDELA

Tukang Cerita:

...Seorang perempuan menengok sebentar adegan ini dari jendela, lantas masuk kembali. Para penonton akan segera tahu, siapa dia sebenarnya.

LAMPU YANG MENYOROT TUKANG CERITAFADE OUT TINGGAL ANAK CLARA, BICARA SENDIRI DI RUANGAN ITU, KADANG DUDUK, KADANG BERDIRI, KADANG BERJALAN

(Mengapa Kau Culik Anak Kami, 2001, Prolog babak II Jakarta, Februari 2039 159160)

Dalam bagian fragmen prolog naskah drama di atas, peristiwa ditampilkan dalam petunjuk suasana pada awal bagian drama dalam rangka menciptakan situasi yang nyata dan menyertakan deskripsi suasana yang menunjukkan peristiwa kerusuhan Mei 1998. Kehadiran suara berupaya menampilkan situasi sejarah secara realis dan tata cahaya untuk mendukung kesuraman peristiwa itu. Hal itu juga digunakan untuk memberikan penekanan dan sebagai pembeda adegan. Sorotan lampu menjadi penanda peralihan adegan dan penguatan terhadap kemunculan tokoh. Tata suara dalam petunjuk pemanggungan pada bagian awal merupakan cara untuk menghadirkan suasana, peralihan ruang, dan pergantian peran.

Drama itu lebih terlihat bagaimana situasi yang lampau ditampilkan dalam monolog tukang cerita. Selain itu, deskripsi suasana dan kejadian muncul dalam bentuk yang jika ditampilkan dalam pertunjukan melalui tuturan lisan (verbal) si tukang cerita. Pola penghadiran tukang cerita digunakan sebagai cara untuk menyiasati detail kronologi historis dan ruang kota yang kemungkinan kecil dapat ditampilkan dalam posisinya sebagai drama yang realis dalam pertunjukan. Monolog tukang celoteh terlihat lebih sebagai orang yang menyikapi kejadian. Pandangan yang ditunjukkan secara langsung mengenai Jakarta yang busuk sekaligus 
merupakan sikap dalam melihat peristiwa tragedi yang menimpa tokoh anak Clara, juga mengenai sikap orang yang tenang dalam melihat kejadian penangkapan yang dalam analoginya juga dapat dilihat sebagai kritik terhadap tafsir publik yang tidak peduli terhadap peristiwa tragedi yang diangkat dalam naskah drama.

Selain itu, dalam pewujudan tokoh, Aku dalam cerita diberikan identitas sebagai anak Clara. Hal tersebut memungkinkan cerita dalam bagian naskah drama itu berelasi dengan cerita lain yang bertema serupa yang dapat disalingpautkan. Dengan demikian, Clara menjadi bagian cerita lain dalam naskah drama meskipun sebenarnya dapat berdiri sendiri sebagai cerita. Pemunculan tokoh Aku menjadi anak Clara menjadi penting untuk dilihat dalam posisinya sebagai naskah dirinya muncul untuk menamai tokoh yang secara logis dalam narasinya berpaut dengan tokoh lain. Dalam naskah, tokoh anak Clara menjadi penamaan, sedangkan dalam bentuk pertunjukkan tokoh anak Clara memerlukan pengondisian yang realis untuk menghadirkannya lengkap dengan eksplorasi tokoh itu atau melalui teknis pertunjukan yang mampu menjadikan tokoh anak Clara sesuai dengan tuntutan naskah dan kelogisan narasi dan latar belakangnya.

Terdapat hal penting yang membedakan naskah drama dengan media lain (cerpen ataupun komik). Drama yang terdiri atas dua babak, babak kesatu dan kedua disatukan sebagai narasi yang padu antara dua waktu dan kondisi masa lalu (Jakarta,13-14 Mei 1998) berdasarkan cerpen "Clara dan Mendatang" (13-14 Februari 2039) dan berdasarkan cerpen “Jakarta 2039”. Empat puluh tahun rentang waktu historis memosikan naskah drama sebagai relay station, yaitu sebagai narasi yang bersifat fiksional berdasarkan pengingatan ulang yang dapat menggambarkan situasi yang digambarkan berdasarkan ingatan mengenai peristiwa lampau, yaitu kekerasan terhadap perempuan Cina yang diperkosa sekaligus sebagai kondisi traumatik yang terjaga pada masa mendatang. Hal itu dirangkum pada awal naskah

...PANGGUNG TERANG BENDERANG. DI LATAR BELAKANG TERLIHAT KOTA JAKARTA. GEDUNG-GEDUNG DI JALAN SUDIRMAN, MONAS, SEMANGGI, JALANJALAN TOL. PAPAN-PAPAN IKLAN RAKSASA. TUKANG CERITAMASUK PANGGUNG. IA SEPERTI SEORANG PENGEMBARA DALAM DONGENG MEMBAWA TONGKAT DENGAN BUNTALAN.
Tukang Cerita:

(Mengipas dengan topinya yang lebar)

Ah... panas sekali. Tahun berapa ini?

(melihat arlojinya)

Ah, tahun.... (sebut tahun ketika dipanggungkan). Sudah berabad-abad saya mengembara, dari ruang yang satu ke ruang yang lain, dari waktu yang satu ke waktu yang lain, belum pernah saya temui kota sepanas ini...manusia macam apa yang bisa hidup dengan kebusukan seperti ini? Betah sekali. Yang bisa hidup bersama kebususkan tentu juga manusiamanusia yang busuk. Ah, penonton! Maaf! Maaf! Saya lupa kalau sudah sampai di tempat pemberi order....Jakarta! Ah, ya, jadi ini Jakarta tahun....(sebut tahun ketika dipanggungkan) hmm... tapi jangan takut, saya punya sebuah cerita tentang kota para penonton sendiri, Jakarta....Jakarta pada bulan Mei 1998.

Naskah drama dalam memosisikan masa lalu dan mendatang menunjukkan bahwa drama sebagai teks sastra berposisi sebagai catalyst, sebagai teks yang berhubungan dengan kekuatan imajinatif pengarang yang menggunakan fiksi sebagai cara untuk menggambarkan "kebaruan" suatu topik sebagai suatu ingatan kultural. Topik mengenai ingatan kekerasan pada Mei 1998 dipersiapkan sebagai kondisi yang muncul kembali sebagai ingatan yang menjadi baru kembali dalam masa kini dan mendatang. Karya sastra menyimpan ingatan mengenai suatu peristiwa. Secara tersirat kondisi kebaruan itu dimunculkan dalam monolog tukang cerita yang sengaja dibiarkan rumpang dalam waktu yang dapat diisi sesuai dengan waktu saat pementasan akan dilakukan. Hal itu menunjukkan bahwa melalui naskah drama memungkinkan menghadirkan ingatan masa lalu mengenai perempuan yang diperkosa dan trauma pada masa kini dan mendatang akan terus hadir dalam upayanya membangun ingatan masyarakat, baik dalam pembacaan terhadap drama sebagai naskah maupun dalam bentuk pertunjukan.

\section{Membangun Monumen Ingatan: Kekerasan, Perempuan yang Diperkosa, dan Trauma}

Persoalan kekerasan dan tragedi pemerkosaan terhadap perempuan Cina dalam tiga karya Ajidarma merupakan peristiwa sentral yang diangkat. Peristiwa tersebut dipertahankan oleh Ajidarma sebagai ingatan dalam setiap karya melalui penghadiran dalam medium yang berbeda. 
Mengenai peristiwa pemerkosaan, sebagai isu kontraversial yang diangkat dari komik Jakarta 2039, kebenaran mengenai peristiwa pemerkosaan massal yang terjadi pada perempuan Cina pada Mei 1998 pun mengemuka dalam perdebatan tersebut. Berikut merupakan pembandingan bagaimana isu tersebut dipertahankan dalam tiga karya.

\section{Cerpen}

Begitulah kameraku, dari wanita tua yang sudah berumur 80 tahun umurnya itu, aku menjadi tahu bahwa diriku bukanlah diriku yang selama ini kukenal. Ternyata aku anak hasil pemerkosaan. Ibuku diperkosa beramai-ramai dalam kerusuhan masal yang melanda Jakarta tanggal 13-14 Mei 1998. Aku lahir tepat Sembilan bulan kemudian pada tanggal 14 Februari 1999. Selama hamil ibuku sakit jiwa.la tidak pernah bicara.la tidak pernah tersenyum. Dan sering membentur-benturkan kepalanya ke tembok. Begitu aku lahir ia langsung sembuh.

...Aku merasa terkutuk dan celaka. Tak seorang pun akan bisa membayangkan bagaimana perasaan seorang wanita yang diperkosa jika tidak mengalaminya sendiri. Diperkosa beramai-ramai bukan karena indah dan menarik, melainkan diperkosa dengan penuh kebencian karena kami adalah orang lain yang tidak dikehendaki, orang lain yang dibenci, bahkan binatang pun tidak pernah dibenci seperti manusia membenci kami...selama empat puluh tahun itu pula kutukan itu mengikutiku selamanya. Ingatan, kenapa manusia mempunyai ingatan? Bahkan lupa macam apapun tidak pernah bisa menghapus kenyataan bahwa aku pernah diperkosa begitu rupa, ditindas, dihina, dan dilecehkan..sudah berapa lama kejadian itu? Aku diperkosa pada tanggal $14 \mathrm{Mei}$ 1998 pukul sepuluh malam, di sebuah bangunan yang temboknya ditulisi dengan makian. Api menyala-nyala di sekitarku dan jeritan wanita-wanita yang diperkosa terdengar di mana-mana. Sembilan bukan kemudian, tepat pada 14 Februari 1999 engkau dilahirkan...

(Dunia Sukab, 2001:135-136)

Fragmen dalam cerpen di atas memperlihatkan tokoh Aku yang berbicara kepada kamera sebagai pengakuan. Kamera dalam narasi tersebut diperlihatkan sebagai pihak yang merekam ingatan mengenai tokoh Aku sebagai anak tokoh wanita tua yang diperkosa pada 13-14 Mei 1998, saat kerusuhan melanda Jakarta. Melalui tokoh Aku yang berbicara sebagai kondisi trauma diperlihatkan akibat dari peristiwa kekerasan tersebut. Narasi tokoh Aku dalam penuturannya membawa pembaca pada situasi sejarah masa lalu yang suram, seolah dirinya berbicara pada kamera. Namun, yang dituju adalah semacam narasi pengakuan dan kesaksian korban serta memperlihatkan kejadian itu menciptakan kondisi psikologis yang buruk bagi wanita tua, ibu tokoh Aku. Fragmen kedua menunjukkan kesaksian dari pihak lain wanita tua. Dalam kesaksiannya, dirinya menunjukkan tekanan secara psikologis sekaligus perasaan yang melibatkan isu rasial mengenai perempuan dan orang Cina secara umum yang tidak dikehendaki keberadaanya. Kejadian itu dianggap sebagai kutukan dan ingatan yang terus mengemuka sebagai beban dan trauma masa lalu yang dihadirkan untuk dipahami. Deskripsi kejadian secara detail dalam peristiwa ditampilkan oleh wanita tua yang dalam keadaan yang sama menjelaskan kelahiran tokoh Aku. Kesaksian tersebut mengingatkan pembaca sebagai pihak

\section{Komik}
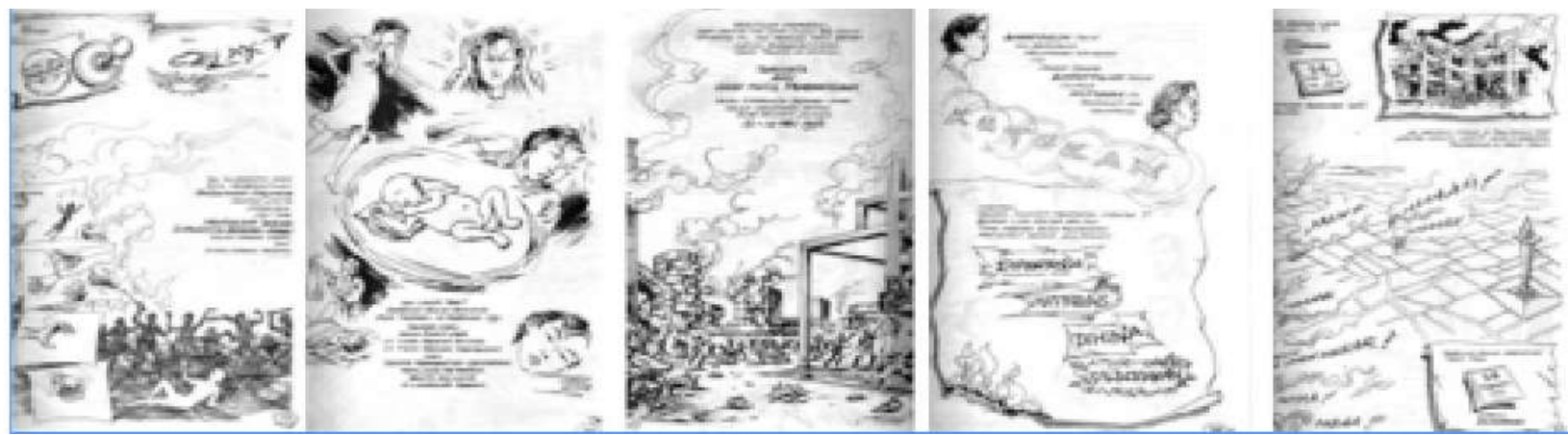

(Jakarta 2039, 2001: hlm.33-37)

" Komik menggambaran atau memberikan ilustrasi cerita tanpa ada penambahan ataupun pengurangan tema cerita yang berarti selain perubahan medium." 
yang seolah diposisikan sebagai pendengar.

Narasi dalam cerpen di atas kemudian digambarkan dalam beberapa panel komik berikut lengkap dengan teks narasi yang sama.

Komik menggambarkan atau memberikan ilustrasi cerita tanpa ada penambahan ataupun pengurangan tema cerita yang berarti selain perubahan medium itu. Penghadiran peristiwa kerusuhan dan pemerkosaan dalam kontras dan closure terhadap perempuan dalam teknik shiluet terhadap eksposur peristiwa pemerkosaan dapat dilihat melalui panel tangan yang mencengkram dan teks yang memperkuat ilustrasi tersebut. Hal itu dilengkapi teks berupa narasi peristiwa serta gambar yang berhubungan dengan kelahiran dalam situasi psikologis yang traumatis dan menekan yang dialami oleh ibu. Terdapat penekanan terhadap kata celaka, diperkosa, ditekan, dihina, dan dilecehkan dalam panel dan jukstaposisi yang berturutan serta penekanan dalam huruf yang tegas.

Keadaan tersebut dilihat sebagai peristiwa yang terjadi di seluruh Jakarta (panel terakhir). Dengan demikian, ide tentang kekerasan dalam hal itu pemerkosaan terhadap perempuan dapat lebih terlihat dalam ilustrasi kejadian yang dibuat dalam situasi genting atau kerusuhan Jakarta pada Mei 1998 yang dibalut dengan narasi yang mengaitkannya dengan keadaan trauma tokoh perempuan tua atau ibu Aku. Tokoh menganggap peristiwa yang menimpanya sebagai kutukan dan kekerasan yang diksriminatif dan menciptakan kondisi yang tidak terlupakan sebagai ingatan.

Berlainan dengan kedua teks di atas sama dengan bahasan sebelumnya. Tokoh ibu Aku dihidupkan dengan menciptakan tokoh Clara tua yang bermonolog. Dalam kejadian dan keadaan yang sama dengan kedua teks di atas dirinya mengungkapkan kejadian yang menimpanya, persis sama dengan cerita di atas, tetapi hanya berbeda dalam mediumnya yang seolah naskah drama itu diperuntukkan untuk pertunjukan. Pergantian adegan terlihat dalam petunjuk pemanggungan yang ditandai oleh perubahan lampu yang menyorot pemain.

\section{Drama}

LAMPU YANG MENYOROT TUKANG CERITA FADE OUT. CLARA TUA BICARA. KADANG DUDUK, KADANG BERDIRI, KADANG BERJALAN.

\section{Clara Tua}

Aku merasa terkutuk dan celaka. Tak seorang pun akan bisa membayangkan bagaimana perempuan diperkosa jika tak mengalaminya sendiri. Diperkosa beramairamai bukan karena indah dan bukan karena menarik, melainkan diperkosa dengan penuh kebencian karena kami adalah orang lain yang tidak dikehendaki. Orang lain yang dibenci. Bahkan binatang pun tidak pernah dibenci seperti manusia membenci kami.

Empat puluh tahun aku selalu berusaha melupakan kejadian itu. Namun, selama empat puluh tahun itu pula kutukan itu mengikuti aku selamanya.

Ingatan, kenapa manusia mempunyai ingatan? Bahkan lupa macam apa pun tidak pernah menghapus kenyataan bahwa aku penrah diperkosa begitu rupa, ditindas, dihina, dan dilecehkan.

Aku benci sekali dengan kelahiranku dan aku benci sekali dengan kelahiranmu. Sudah jelas, aku melahirkan anak iblis. Anak pemerkosa, entah yang mana.

Sudah berapa lama kejadian itu?Aku diperkosa pada tanggal 14 Mei 1998 pukul sepuluh malam.Api menyala-nyala di sekitarku.Jeritan perempuan-perempuan yang diperkosa terdengar dimana-mana.

Sembilan bulan kemudian, tepat pada 14 Februari 1999, engkau dilahirkan. Selama Sembilan bulan aku merasa bagaikan ada seekor ular bertanduk di dalam perutku.....

AIR MATA CLARA TUA MENETES, MENGALIR DI PIPI KANAN KIRI...

(Mengapa Kau Culik Anak Kami, 2001, Monolog Clara Tua: 165-167)

Kesaksian dan pengakuan wanita tua dalam naskah drama dituliskan sebagai monolog "Clara Tua". Peristiwa dalam naskah drama dengan demikan bertautan dengan cerita dalam cerpen Clara. Detail peristiwa dan kejadian serta situasi pemerkosaan dan perasaan diungkapan dengan cara monolog dan yang juga penting dilihat adalah petunjuk pemeranan yang menuntut pemeran oleh Clara tua dalam keadaan yang jelas serta situasi tokoh yang sedih dan trauma melalui gerakgerik sebagai bentuk trauma dan tangisan yang menunjukkan secara kinetis ekspresi tokoh Clara tua.

Ada yang penting untuk dilihat bahwa paralelitas antara cerita Clara sebagai sumber alih wahana dalam drama yang bertautan menjadi logis dengan Jakarta 2039. Adapun kepaduan 
naratifnya dibangun oleh kesamaan inti cerita yang juga merujuk pada perempuan korban pemerkosaan pada masa kejatuhan Orde Baru. Clara dengan demikian dihadirkan sebagai masa lalu dan "Jakarta 2039" adalah kini. Tokoh Clara pun demikian muncul sebagai suatu yang logis dalam cerita. Dirinya menggantikan tokoh ibu tua korban pemerkosaan dalam narasi cerpen ataupun komik, terlebih tokoh Clara yang memang diidentifikasikan sebagai identitas perempuan Cina yang mengalami trauma yang berat akibat kekerasan rasial dan perkosaan yang menimpanya. Tokoh Aku sebagai perempuan anak korban pemerkosaan menunjukkan keadaan trauma sekaligus menjadi korban, tetapi dalam bentuk yang lain, yaitu korban ingatan akibat sejarah kelam masa lalu ibunya.

\section{Simpulan}

Berdasarkan pembahasan, terdapat tiga hal yang dapat dilihat sebagai ide utama dalam ketiga karya, baik cerpen, komik, maupun naskah drama: (1) penggambaran peristiwa Kota Jakarta dalam masa kejatuhan Orde Baru; (2) kerusuhan dan kekerasan, yaitu pemerkosaan perempuan Cina pada Mei 1998; (3) masa depan yang traumatis yang dialami korban. Dengan cara demikian, pengarang berupaya menghadirkan kembali ingatan yang sama mengenai peristiwa kekerasan. Cerpen sebagai media pertama yang ditulis satu tahun setelah tragedi Mei 1998 diulang kembali dalam media yang berbeda dalam komik (2001) dan naskah drama (2001).

Dalam pengalihwahanaannya, transfer gagasan atau tema dari satu media ke media lainnya berupaya terus memosisikan tiga karya (cerpen, komik, dan naskah drama) sebagai media penyimpanan ingatan sekaligus sebagai cara untuk memberikan usia yang lebih panjang terhadap karya utama. Selain itu, tiga karya Jakarta 2039 merupakan upaya untuk masuk dan memengaruhi memori kultural mengenai peristiwa kekerasan perempuan Cina pada Mei 1998. Peristiwa tersebut dalam posisinya sebagai memori kolektif melibatkan pertarungan kebenaran atas fakta antara apa yang disimpan, dipertahankan, dan diproduksi ulang dalam karya sastra dengan "kebenaran" lain yang merentang sebagai opini publik (meyakini kebenaran atau membantah) dengan sumber ingatan yang lain: penelitian, fakta hukum, dan pelbagai laporan jurnalistik.

Dalam keadaan itulah upaya menjadikan karya sastra sebagai teks untuk membangun monumen ingatan mengenai peristiwa kekerasan terhadap perempuan Cina pada Mei 1998, yang bahkan terus direproduksi atau ditulis ulang, menjadi bagian dari pertarungan atas fakta sejarah yang simpang siur. Dengan kata lain, teks sastra Jakarta 2039 dan pengalihwahanaannya sebagai upaya untuk melawan pelupaan masyarakat terhadap sejarah juga muncul sebagai upaya untuk mempertahankan ingatan dan memahami peristiwa masa lalu dalam sisi "kebenaran" yang lain. Proses pengalihwahanaan cerpen "Jakarta 2039", baik ke dalam komik maupun naskah drama, dalam keberadaannya menghasilkan suatu pemahaman yang menunjukkan bahwa teks sastra tidak memiliki kuasa untuk menghadirkan kebenaran tunggal atas peristiwa dan membangun monumen ingatan serta keberadaannya tidak serta-merta dapat menjadi memori kebudayaan di masyarakat sebagai satu-satunya keadaan yang dipercaya dan diyakini sebagai kebenaran mengenai peristiwa kekerasan dan pemerkosaan terhadap perempuan Cina pada Mei 1998. Sedikitnya dari apa yang telah diupayakan oleh Ajidarma kini berselang lima belas tahun Ajidarma menyediakan monumen imajiner bagi siapa pun yang ingin kembali diingatkan dan merayakan bahwa Jakarta dan bangsa ini dibangun di atas sejarah penistaan terhadap martabat kemanusiaan.

\section{Catatan Akhir:}

${ }^{1}$ Puisi pertamanya dimuat dalam rubrik "Puisi Lugu" majalah Aktuil. Pernah bekerja sebagai wartawan lepas di Merdeka, menerbitkan majalah kampus Cikini, majalah film Sinema Indonesia (1980) dan mingguan Zaman. Pernah menjabat sebagai redaktur pelaksana Jakarta-Jakarta (1982) dan menyelesaikan studinya di IKJ (1994). Kumpulan sajaknya: Granat dan Dinamit (1975), Mati Mati Mati (1975), Bayi Mati (1978), dan Catatan-Catatan Mira Sato (1978). Kumpulan cerpennya Manusia Kamar (1978), Penembak Misterius (1993), dan Saksi Mata (1995) mendapatkan penghargaan Pusat Pembinaan dan Pengembangan Bahasa, Dilarang Menyanyi di Kamar Mandi (1995) menerima hadiah sastra ASEAN (South East Asia Write Award), Sebuah Pertanyaan untuk Cinta (1996), Negeri Kabut (1996), Matinya Seorang Putri Telanjang (1998), Iblis Tidak Pernah Mati (1998), Atas Nama Malam (1999), Dunia Sukab (2001), Kematian Doni Osmond (2001), Sepotong Senja untuk Pacarku (2002), Aku Kesepian Sayang Datanglah Menjelang Kematian (2004), dan Linguae (2007). Novel yang pernah diterbitkan: Jazz Parfum 
dan Insiden (1996), Negeri Senja (2003), Biola Tak Berdawai (2004), Kitab Omong Kosong (2004), Kalatidha (2007), Nagabumi (2009), karya Tulis dalam esai/prosa: Ketika Jurnalisme Dibungkam Sastra Harus Bicara (1997) dan Surat dari Palmerah (2002). Pada 2005 memperoleh penghargaan Kharulistiwa Literary Award. Dirangkum dan ditambahkan berdasarkan Ensiklopedi Sastra Indonesia (Edisi Revisi), Bandung, Titian IImu. 2009, hIm. 866-867.

2 Terdapat beberapa dokumen tertulis mengenai posisi terutama kekerasan yang menimpa etnik cina dalam kaitannya dengan negara. Untuk kekerasan pada masa keruntuhan Orde Baru dan awal masa reformasi; Jemma Purdey, Anti Chinese Violence in Indonesia, 1996-1999, Singapore University Press, 2006. Kekerasan spesisifik pada kerusuhan Mei 1998; Ester IY dan Raymond R.S, Reka Ulang Kerusuhan Mei 1998, Solidaritas Nusa Bangsa, 2005 dan Raymond R.S (ed), Kerusuhan Mei 1998 Fakta, Data dan Analisa, Solidaritas Nusa Bangsa dan APHI, 2007. Serta Charles A. Coppel, Tionghoa Indonesia dalam Krisis, Pustaka Sinar Harapan, 1994. Selain itu. Lihat juga tulisan Surya Tjandra, "Kerusuhan Rasial dan Legitimasi Pemerintah" dalam Cokin So What Gitu Loh! Ivan Wibowo (ed.) Jakarta, Komunitas Bambu, 2008. HIm. 23-28. Dalam Tulisannya Thandra meruntut kejadian kerusuhan rasial tanggal 13-14 Mei 1998. Dirinya mempertanyakan komitemen pemerintah sebagai pihak yang bertanggung jawab dalam peristiwa tersebut, termasuk peristiwa pemerkosaan yang menimpa perempuan etnik Cina ketika itu. Lihat pula kejatuhan Orde Baru dalam perspektif politik dan ekonomi dalam Eric Hiariej, Materialisme Sejarah Kejatuhan Soeharto: Pertumbuhan dan Kebangkrutan Kapitalisme Orde Baru, 2005, Yogyakarta: IRE Press.

${ }^{3}$ Seno Gumira Ajidarma, Surat dari Palmerah: Melawan Ketakutan, Jakarta, Minggu 19 Juli 1998 dalam Surat dari Palmerah: Indonesia dalam Politik Mehong: 1996-1999. Jakarta, KPG, 2002, hlm. 266-267. Lihat juga secara spesisik wawancara dengan Romo I Sandyawan Sumardi S.J. yang menyatakan bahwa pelaku kerusuhan dan pemerkosaan terhadap perempuan cina adalah jaringan kejahatan terorganisasi, berpola sistematik. hlm.. 274-285.

${ }^{4}$ Mengenai subjek dalam kongnisinya dan bagaimana dirinya berfikir dan mengingat, lihat Herebert D. Zimmer dkk, "Visuospatial Thinking, Imagination and Remembering", khusus untuk bahasan mengenai sistem kognitif dan mengingat lihat subbahasan "Cognitive System for Visuospatial Thinking and Remembering", yaitu dalam proses mengingat secara kognitif seseorang menggenerasikan gambar ke dalam input verbalnya yang berasosiasi dengan mental dan dirinya kemudian muncul dan diungkap dalam pengaruh ingatan dan imajinasi yang mewujud dalam proses berbahasa. Svein Magnussen dan Tore Helstrup (Ed), Everyday Memory, New York, Psychology Press, 2007, hlm. 29-31.

${ }^{5}$ Fiksi digunakan sebagai cara menyampaikan hal yang tidak dapat disampaikan secara langsung, termasuk oleh laporan jurnalistik, selanjutnya Lihat Seno Gumira Ajidarma, Ketika Jurnalisme Dibungkam Sastra Harus Bicara, Yogyakarta, Bentang Budaya, 1997.

${ }^{6}$ Dalam apresiasi sastra di institusi pendidikan, karya sastra karangan Seno Gumira Ajidarma, misalnya, cerita pendek "Clara", digunakan sebagai objek di bebeberapa Universitas, di Universitas Negeri Jakarta atau Universitas Indonesia Jurusan Sastra Indonesia, di tingkat sarjana. Karya sastra itu dirujuk dalam keterkaitannya dengan peristiwa Mei 1998 dan memperdebatkan kebenaran mengenai kebenaran terhadap peristiwa tersebut. Cerpen "Clara" itu pun diterjemahkan ke dalam bahasa Inggris sebagai Clara oleh Michael H. Bodden; dibacakan oleh Bruce Kochis dan Christina Alfar di University of Washington-Bothell, Seattle (1999), oleh Jason Mitchell dan Marl Babbdi University of Victoria, Victoria Bc (1999) dimuat dalam jurnal Indonesia No. 68 (Cornell University), Oktober 1999, dan diterjemahkan ke dalam bahasa Jepang sebagai Kurara, Rape Saretra Joseino Monogatari oleh Mikihiro Moriyama; dimuat dalam berkas Seno Gumira Ajidarma.

7 Untuk komik, dalam peluncuran komik Jakarta 2039, kritikus Bramantyo mempertanyakan hak pengarang memublikasikan pengalaman sangat pribadi dari tragedi kemanusiaan itu, seolah-olah pengarang malah mengobjekkan para korban. Menurut Seno, sebagai manusia kita bukan hanya berhak memublikasikan karya tragis kemanusiaan itu menjadi sebuah renungan sejarah, tetapi juga wajib membagikan keprihatinan itu. "Harapannya, kejadian yang sempat mencoreng nama baik Indonesia di luar negeri itu jangan sampai terulang kembali di masa mendatang". Seno mengaku bahwa dirinya tidak ingin mengeruk keuntungan dari pengalaman pahit para korban, apalagi membangkitkan kembali luka batin yang mereka alami. la dan Zacky hanya ingin membagikan kepada masyarakat pada masa 40 tahun mendatang. Lihat "Diluncurkan, komik cerpen tragedi Mei 1998", Kompas Online - Rabu, 16 Mei 2001

${ }^{8}$ Astrid Erll menulis bahwa media fiksional, baik novel maupun genre film feature sebagai, "Characterized by their power to shape the collective imagination of the past.. they create images of the past which resonate with cultural memory. Usually, such fiction can neither be called "valuable literature". Lebih lanjut dirinya melihat bagaimana karya sastra sebagai medium yang secara simultan membangun dan mengobservasi ingatan. lihat: Astrid Erll, "Literature, Film, and the Mediality of Cultural Memory" dalam Op.Cit., 2008, hlm. 380-392.

${ }^{9}$ Persoalan kekerasan dalam karya sastra karangan Seno Gumira Ajidarma telah didaftar dan diidetifikasi oleh Nurhadi. Dalam simpulannya kekerasaan oleh negara merupakan tema dominan yang dikembangkan. Termasuk dalam cerpen "Jakarta 2039", Nurhadi melihat tema utama yang dikembangkan adalah mengenai pemerkosaan masal, kerusuhan dan penjarahan sebagai tema tambahan, dan rasisme sebagai sisipan. Selain itu, Nurhadi pun melihat bahwa cerpen tersebut mengacu pada persitiwa Mei 1998. Nurhadi, “Aspek Kekerasan sebagai Refleksi Kondisi Sosial Politik dalam Karya-Karya Seno Gumira Ajidarma, artikel 
yang diintisarikan berdasarkan disertasi Program Studi IImu Sastra Program Pascasarjana Universitas Gadjah Mada di bawah bimbingan Prof. Dr. Rh. Djoko Pradopo dan Prof. Dr. Bakdi Soemanto, S.U.; dipresentasikan dalam seminar The First IGSC (International Graduate Student Conference) Pascasarjana, Universitas Gadjah Mada pada tanggal 1-2 Desember 2009.

${ }^{10}$ Mengenai isu pemerkosaan, Pammela Alen melihat posisi Ajidarma sebagai penulis yang sulit untuk dikategorisasi, gaya jurnalistik dalam tulisannya, serta pilihan topik kontraversial. Allen mengambil contoh cerpen Clara tentang perempuan Cina yang diperkosa dalam serangan kekerasan terhadap etnik Cina-Indonesia pada Mei 1998. Lihat Pamela Allen, "Seno Gumira Ajidarma: Connscience of The People", New Zealand Journal of Asian Studies 4, 2, December, 2002, hlm. 177.

${ }^{11}$ Pammela Allen juga mengulas masalah peluncuran komik Jakarta 2039. Dia menulis, pekerjaan yang menarik kontroversi, termasuk tuduhan bahwa kedua penulis itu (Ajidarma dan Zhaky) mengungkit pengalaman yang sangat pribadi dan bahwa, pekerjaan dibatasi pada objektivikasi korban. Tanggapan untuk pekerjaan itu juga memberikan keunggulan publik untuk pertanyaan yang sebelumnya telah dinyatakan hanya sebagai desas-desus atau gosip, yaitu, 'Apakah kekerasan seksual sebenarnya memang terjadi? 58 Sejumlah peserta peluncuran buku Seno publik menyuarakan skeptisisme mereka tentang kebenaran laporan perkosaan. Lihat, Pamela Allen, dalam Op.Cit., 2003.

\section{DAFTAR PUSTAKA}

Ajidarma, Seno Gumira. 2002. Surat dari Palmerah: Indonesia dalam Politik Mehong: 19961999. Jakarta: KPG.

ᄀ. Budaya.

2001.Mengapa Kau Culik Anak Kami: Tiga Drama Kekerasan Politik, Yogyakarta, Galang Press.

2001. Dunia Sukab: Sejumlah Cerita. Jakarta: Kompas.

Ajidarma, Zacky. 2001. Jakarta 2039: 40 Tahun 9 Bulan setelah 13-14 Mei 1998. Yogyakarta: Galang Press.

Allen, Pamela . 2002. "Seno Gumira Ajidarma: Connscience of The People". Dalam New Zealand Journal of Asian Studies 4, 2, Desember.

.2003. "Contemporary Literature from the Chinese Diaspora in Indonesia". Dalam Asian Ethnicity, Vol.4. No. 3., Oktober.

Assmann, Aleida. 2008. "The Dynamics of Cultural Memory between Remembering and Forgetting" dalam Cultural Memory Studies: An International and Interdisciplinary Handbook, Astrid Erl dan Nunning (Ed.). New York: Walter de Gruyter.

Boyer Pascal, James V. Wertsch (Ed.) .2009. Memory in Mind and Culture. New York: Cambridge.

Cloud, Scott Mc. 2008. Understanding Comics. Memahami Komik. Terjemahan S. Kinanti. Jakarta: KPG

Coppel, Charles A. 1994. Tionghoa Indonesia dalam Krisis. Pustaka Sinar Harapan.

Ellestron, Lars (Ed.). 2010. Media Borders, Multimodality and intermedialiality. New York: Palgrave Macmilan.

Ester, Raymond R.S, 2005.Reka Ulang Kerusuhan Mei 1998. Jakarta: Solidaritas Nusa Bangsa.

Hiariej, Eric. 2005. Materialisme Sejarah Kejatuhan Soeharto: Pertumbuhan dan Kebangkrutan Kapitalisme Orde Baru. Yogyakarta: IRE Press.

L., Henry (dkk.). 2009. "Role of Repeated Retrieval in Shaping Collective Memory". Dalam Memory in Mind and Culture, Pascal Boyer dan James V. Wertsch (Ed.). New York: Cambridge.

Magnussen Svein, Tore Helstrup (Ed.). 2007. Everyday Memory. New York: Psychology Press.

Nurhadi. 2009. “Aspek Kekerasan sebagai Refleksi Kondisi Sosial Politik dalam Karya-Karya Seno Gumira Ajidarma". Makalah dalam Seminar The First IGSCI (International Graduate Student Conference) Pascasarjana, Universitas Gadjah Mada pada tanggal 1-2 Desember.

Purdey, Jemma. 2006. Anti Chinese Violence in Indonesia, 1996-1999. Singapura: Singapore University Press.

Raymond, R.S (Ed.).2007. Kerusuhan Mei 1998 Fakta, Data dan Analisa.Jakarta: Solidaritas Nusa Bangsa dan APHI.

Rigney, Ann. 2008. "The Dynamics of Remembrances: Text Between Monumentality and Morphing". Dalam Cultural Memory Studies: An International And Interdisciplinary Handbook, Astrid Erll, dkk. (Ed.). Berlin: Walter de Gruyter.

Tim Redaksi Ensiklopedi Sastra Indonesia. 2009. Ensiklopedi Sastra Indonesia (Edisi Revisi). Bandung: Titian Ilmu.

Wibowo, Ivan (Ed.). 2008. Cokin So What Gitu Loh! Jakarta: Komunitas Bambu. 